\title{
Does Bad Credit Affect the Profitability of State-Owned Banks Listed on the Indonesia Stock Exchange?
}

\author{
Ramon Arthur Ferry Tumiwa \\ Economics Faculty, Universitas Negeri Manado, Tondano 95618, Indonesia
}

\begin{abstract}
This study aims to examine and analyze whether bad credit have a significant effect on the profitability of stateowned banks listed on the Indonesia Stock Exchange.This study uses data from state-owned bankslisted on the Indonesia Stock Exchange during the period 2010 to 2017. The analyzed banks are 4 banks based on sample criteria. The analysis method used is panel data analysis by using Microsoft Exel and Eviews 10 software.The results of this study found that bad credit has a negative and significant impact on bank profitability where the greater the bad credit can lead to the smaller the ability of banks to make profit
\end{abstract}

Keywords: bad credit, profitability, state-owned banks, Indonesia Stock Exchange

DOI: $10.7176 / \mathrm{RJFA} / 11-2-08$

Publication date: January $31^{\text {st }} 2020$

\section{Introduction}

The bank is a financial intermediary institution that bridges the debtor with the creditor, or the institution that connects the parties that have excess funds with those who need funds. This can be seen from the activities of banks in collecting funds from the public through demand deposits, deposits and savings, and subsequently channeling these funds through lending to parties in need, conducting overseas payment transactions, foreign exchange services and other activities (Siamat, 2001). Banking is also called financial intermediary, which is a liaison institution between those who need funds and those who have excess funds (Budisantoso and Triandaru, 2006). The distribution of funds by banks is done through lending, which is better known in the community by the name of credit.

Banks and other financial institutions are specialized businesses which are strongly influenced by a number of conditions that are unique to the banking business, such as government regulations and access to government safety nets that include deposits and loans (Tumiwa et al., 2013)

In the banking world, there are many types of credit offered to the public as prospective customers, including commercial or retail credit administration, namely loans granted to facilitate customer activities in which the business sector is trading (intended to finance the needs of the business world) in the form of revolving credit or credit in the form of non revolving.

Commercial or retail credit customers generally come from the general public so that it does not rule out the possibility of a very large bottleneck due to their uncertain income in the business development process. Weak binding of collateral that is less than optimal such as the addition of sufficient unsecured loans, can not realize credit guarantees and banks are not able to master the collateral as soon as there is a sign of credit that is growing towards non-performing loans. The reduced economic activity and high credit interest rates will make it difficult for customers to repay loans or loans that have been received.

As a sector engaged in banking and an economic entity the bank provides financial reports to show the information and financial position listed in the financial statements that will be used by investors to predict potential cash receipts from dividends and interest. The amount of profitability of the company is an important indicator in the financial statements where profitability is used as a basis for investment decision making and predictions to predict future earnings changes. Return on Assets (ROA) is one indicator to measure a company's financial performance and is a profitability ratio that is used to measure the effectiveness of a company in generating profits by utilizing its total assets. ROA is the ratio between profit after tax to total assets. ROA focuses on the company's ability to obtain earnings in the company's operations (Siamat, 2001).

In every transaction that occurs at the bank, there is a possibility that the customer is late making payments or is unable to pay. Credit that cannot be paid is called bad credit or non-performing loan (NPL).

NPL is an indicator of the health of the quality of bank assets. The indicator is a basic financial ratio that can provide information on the assessment of capital conditions, profitability, credit risk, market risk and liquidation. Asset quality assessment is an assessment of the condition of bank assets and the adequacy of credit risk management. This means that NPL is an indication of a problem in the bank which if it does not immediately get a solution it will have a dangerous impact on the bank.

The following is the data of Bad Credit (NPL), Total Credit and Profitability (ROA) of Bank BNI as follows: 
Table 1. Bad Credit, Total Credit and Profitability Data from Bank BNI (In million rupiah)

\begin{tabular}{|c|c|c|c|c|}
\hline Year & $\begin{array}{c}\text { Bad Credit } \\
\text { (NPL) }\end{array}$ & Total Credit & $\begin{array}{c}\text { Percentage } \\
(\%)\end{array}$ & $\begin{array}{c}\text { Profitability } \\
\text { (ROA) }\end{array}$ \\
\hline 2010 & 811.410 & 136.356 .959 & $0.59 \%$ & $1.65 \%$ \\
\hline 2011 & 1.581 .220 & 163.533 .423 & $0.96 \%$ & $1.94 \%$ \\
\hline 2012 & 4.329 .200 & 200.742 .305 & $2.15 \%$ & $2.11 \%$ \\
\hline 2013 & 4.138 .417 & 250.637 .843 & $1.26 \%$ & $2.34 \%$ \\
\hline 2014 & 4.193 .876 & 277.622 .281 & $1.51 \%$ & $2.59 \%$ \\
\hline 2015 & 5.138 .759 & 326.105 .149 & $1.57 \%$ & $1.79 \%$ \\
\hline 2016 & 9.211 .661 & 393.275 .392 & $2.34 \%$ & $1.89 \%$ \\
\hline 2017 & 7.234 .126 & 441.313 .566 & $1.63 \%$ & $1.94 \%$ \\
\hline
\end{tabular}

Source: www.idx.co.id (Processed, 2019)

Table 1 above shows that Bank BNI's profitability increased from 2010 to 2014 and decreased in 2015 while 2016 to 2017 increased. However, bad credits indicated by NPLs tend to increase from year to year. This can pose a great risk to the bank as a state-owned bank. The same thing happened to Bank Mandiri as follows Table 2.

Table 2. Bad Credit, Total Credit and Profitability Data from Bank Mandiri (In million rupiah)

\begin{tabular}{|c|c|c|c|c|}
\hline Year & $\begin{array}{c}\text { Bad Credit } \\
\text { (NPL) }\end{array}$ & Total Credit & $\begin{array}{c}\text { Percentage } \\
(\mathbf{\%})\end{array}$ & $\begin{array}{c}\text { Profitability } \\
\text { (ROA) }\end{array}$ \\
\hline 2010 & 2.231 .187 & 203.636 .955 & $0.82 \%$ & $2.04 \%$ \\
\hline 2011 & 3.756 .623 & 269.130 .432 & $1.39 \%$ & $2.3 \%$ \\
\hline 2012 & 4.048 .181 & 332.643 .019 & $1.21 \%$ & $2.52 \%$ \\
\hline 2013 & 5.252 .183 & 396.769 .382 & $1.32 \%$ & $2.56 \%$ \\
\hline 2014 & 6.029 .254 & 444.435 .737 & $1.35 \%$ & $2.41 \%$ \\
\hline 2015 & 8.867 .336 & 494.522 .154 & $1.79 \%$ & $2.34 \%$ \\
\hline 2016 & 11.402 .536 & 556.752 .621 & $2.04 \%$ & $0.72 \%$ \\
\hline 2017 & 11.750 .919 & 602.168 .145 & $1.95 \%$ & $0.38 \%$ \\
\hline
\end{tabular}

Source: www.idx.co.id (Processed, 2019)

Table 2 above shows that Bank Mandiri's profitability increased from 2010 to 2013 and decreased from 2014 to 2017. Average NPL at Bank Mandiri increased from 2010 to 2016. and decreased in 2017.

The purpose of this study is to test and analyze whether bad credits have a significant effect on the profitability of state-owned banks listed on the Indonesia Stock Exchange.

The results obtained will be used as material information and input for investors and state-owned bank decision makers in overcoming profitability in banks and to answer the inconsistency of previous research on the relationship between bad credit and profitability.

In addition, it can be used as a study material for further research in examining the same problems in the future

\section{Profitability}

Profitability is the profit that a company earns over a period of time to reflect the company's capabilities. According to Munawir (2002), Profitability is one of the attractive factors for shareholders as it triggers the dividend income paid from the profit or profit of the company. In addition, the increase in corporate profits will trigger stock market price increases and the potential for capital gains. Management is also very interested in profit because it is often used as a measure of performance.

The regular levels of profitability as well as the rising tendency or profit trend are important factors that analysts need to consider in assessing a company's profitability. High profitability for management or others, is more important than big profits.

Profitability is the ability that a company achieves over a given period. The basis of profitability assessment is a financial report consisting of a balance sheet and a company expense. Based on these two reports it will be possible to determine the analysis results of a number of ratios and then these ratios are used to evaluate certain aspects of the company's operations.

Profitability ratio analysis aims to measure a company's ability to profit, in relation to sales, assets, and capital. So profitability can be used as a benchmark or an overview of the effectiveness of management's performance reviews of profitability compared to sales and investment results.

This ratio is intended to measure the company's ability to make a profit. In this research to measure profitability can use Return on Assets (ROA). This ratio is used to measure bank management's ability to earn (overall) profit. The larger the ROA of a bank, the greater the profitability of the bank and the bank's position in 
terms of asset utilization.

ROA calculations are: (1) EBT is the bank's profit before tax deduction, (2) Total Activities are all bankowned activities, which include: Launch Activities, Fixed Activity. According to Bank Indonesia, the ROA standard is approximately $1.5 \%$.

\section{Bad credit}

Bad credit is a condition in which a customer is no longer able or unable to pay any or all of his or her obligations to the bank as in a previous agreement. (Kuncoro dan Suhardjono, 2002). Bad credit is a credit that is subject to repayment difficulties due to factors or elements of the will or due to conditions beyond the creditor's ability (Suharno, 2003). Bad credit is a situation where a customer is no longer able to pay some or all of his or her obligations to the bank as he or she has promised. Bad Credit according to Bank Indonesia's terms are those that are classified as Lack of Collectability (KL), Doubt (D), and Bad (M).

According to Tumiwa et al (2013), credit risk is defined as the risk associated with the failure of the client to pay their obligations or the risk that the debtor cannot repay his debt. Credit risk can come from a few things: (1) It is possible that a loan provided by a bank or an obligation purchased by a bank is unpaid. (2) It does not fulfill the obligations that the bank is involved in through another party, such as failure to fulfill its obligations on the derivative contract. (3) Solutions with exchange rates, interest rates and derivative products.

Another form of credit risk is settlement risk that arises when two foreign exchange payments are made on the same day; this risk occurs when the other party's counterparty may default on the institution's payment. On settlement day, the total loss of the default counter party is equal to the full amount due.

In this study the level of credit risk is improved with NPLs because NPLs can be met with productive activities owned by a bank.

NPLs have a negative impact on banking performance. The higher the NPL, the lower the performance or profitability of banking. This is in line with the fact that having a bad credit score compared to its productive activities can lead to an opportunity for income and credit given, thus reducing profitability and negatively impacting the bank's profitability. Every bank should keep its NPL below 5\%. This is in line with Bank Indonesia's provisions.

Bad credit can generally affect a company's profitability. What causes bad credit is the decline in economic activity and high credit rates so that customers who do credit can not pay the bank's fixed installments. If there is no bad credit then the profitability level goes up but instead if there is bad credit then the profitability level goes down.

Based on the above thinking, the hypotheses that can be formulated are as follows:

H0: $\quad$ Bad credit does not have a significant impact on the profitability of state-owned banks listed on the Indonesian Stock Exchange.

H1: Bad credit has a significant impact on the the profitability of state-owned banks listed on the Indonesian Stock Exchange.

\section{Research Methods}

This study is a quantitative study using associative methods. The source of data used in this study is the financial statements from 2010 to 2017 on the banking sub-sector listed on the Indonesian Stock Exchange.

The population in this study is the Financial Report 2010-2017 of all state-owned banks listed on the Indonesia Stock Exchange. The sampling technique used in this study is using purposive sampling method. As for the sampling criteria with the purposive sampling method as follows: (1) Banking Subsidiary Listed on the Indonesian Stock Exchange, (2) Financial Statements during the period 2010-2017, (3) Data collected is audited and published company data.

So the sample taken in this study is Financial Report from 2010-2017 on Bank BRI, Bank BNI, Bank Mandiri, and Bank BTN. The data analysis technique used in this study uses panel data. And in this study using Microsoft Exel and Eviews 10 software data processing tools.

\section{Results and Discussions}

Descriptive Analysis aims to provide an explanation of the percentage and average value of the variables used in the study including the dependent variable (Y) namely Profitability and the independent variable (X) used is Bad Credit so it will provide a clearer picture of the variables being studied. Based on statistic test results obtained from 4 companies sampled for 8 years. The following is a summary of descriptive statistics using eviews 10 . 
Table 3. Descriptive Statistics Results

\begin{tabular}{|c|c|c|}
\hline Explanation & ROA? & NPL? \\
\hline Mean & 2.020000 & 1.607813 \\
\hline Min & 0.380000 & 0.590000 \\
\hline Max & 3.410000 & 3.220000 \\
\hline Std.Dev & 0.811820 & 0.716347 \\
\hline
\end{tabular}

Source: secondary data processed (Eviews 10)

The statistical test results using eviews 10 are outputs that describe the results of the mean, maximum, minimum, and standard deviation of the dependent and independent variables, so that it can be seen statistically how the description of the variable is. NPL has a mean value of 2.020000 to the profitability of banks. The bank's Max NPL value is 3.220000 to profitability and the minimum value is 0.590000 .

ROA has a mean value of 2.020000 which means that the average company's ability to utilize assets to produce profitability is 2.020000 . The highest value for the company's ability to use assets to produce company profitability is 3.410000 and the lowest is 0.380000 .

Model Selection Test

Data management is done by panel data analysis using E-views 10 software. There are three models used in panel data regression, namely: (1) Common Effect Model, (2) Fixed Effect Model (FEM), and (3) Random Effect Model (REM), each model has advantages and disadvantages of each. The choice of the model depends on the assumptions used by the researcher and the fulfillment of the requirements for correct statistical data processing, so the results can be accounted for statistically. Therefore, the first step that must be done is to choose the right model from the three available models. Panel data that has been collected is revised using the Common Effect model, the results of which can be seen in table 3. Whereas the regression results with the Fixed Effect model can be seen in table 4 .

Table 4. Regression Results using Common Effect models

\begin{tabular}{crrrr}
\multicolumn{1}{c}{ Variable } & Coefficient & Std. Error & t-Statistic & Prob. \\
\hline \hline C & 3.375363 & 0.242777 & 13.90312 & 0.0000 \\
NPL? & -0.842986 & 0.138286 & -6.095943 & 0.0000 \\
\hline \hline R-squared & 0.553309 & Mean dependent var & 2.020000 \\
Adjusted R-squared & 0.538419 & S.D. dependent var & 0.811820 \\
\hline \hline
\end{tabular}

Source: secondary data processed (Eviews 10)

Table 5. Regression Results using Fixed Effect models

\begin{tabular}{ccrrr} 
Variable & Coefficient & Std. Error & t-Statistic & Prob. \\
\hline \hline C & -0.339326 & 0.213083 & -1.592457 & 0.1229 \\
NPL? & 2.565572 & 0.352864 & 7.270709 & 0.0000 \\
\hline \hline & & & \\
\hline \hline
\end{tabular}

Cross-section fixed (dummy variables)

\begin{tabular}{llll}
\hline \hline R-squared & 0.698062 & Mean dependent var & 2.020000 \\
Adjusted R-squared & 0.653330 & S.D. dependent var & 0.811820 \\
\hline
\end{tabular}

Source:

secondary data processed (Eviews 10)

The Chow Test is then performed. The test is required to select the model that is most appropriate between the Common Effect or Fixed Effect model. This test is hypothesized.

$\mathrm{H} 0=$ Common Effect Method

H1 = FEM Method

The following Results from the Chow Test can be seen in table 6 
Table 6. Chow Test Results

\begin{tabular}{lrrr}
\hline \hline Effects Test & Statistic & d.f. & Prob. \\
\hline \hline Cross-section F & $\begin{array}{r}4.314694 \\
12.532597\end{array}$ & $(3,27)$ & 0.0131 \\
Cross-section Chi-square & $=$ & 3 & 0.0058 \\
\hline \hline & $=$ & $=$ &
\end{tabular}

The results from the Chow Test in table 6 indicate that the p-value (Prob) is less than 0.05 , indicating that $\mathrm{H} 0$ which states the model following the Common is rejected. Therefore the model selected is Fixed Effect.

And then perform the regression with the Random Effect model, to determine the exact panel regression model. Results from the regression using the Random Effect model can be seen in table 7.

Table 7. Regression Results using Random Effect Model

\begin{tabular}{crcrr}
\hline \hline Variable & Coefficient & Std. Error & t-Statistic & Prob. \\
\hline \hline C & 3.128534 & 0.280398 & 11.15746 & 0.0000 \\
NPL? & -0.689467 & 0.154351 & -4.466879 & 0.0001 \\
\hline \hline R-squared & 0.365212 & Mean dependent var & 1.307702 \\
Adjusted R-squared & 0.344052 & S.D. dependent var & 0.634554 \\
\hline
\end{tabular}

Source: secondary data processed (Eviews 10)

Both the table 5 results from the regression using the Fixed Effect model and table 7 represent the Random Effect, all of which show that bad credit (NPL) significantly affects the firm's profitability (ROA).

But to decide which model to use. Therefore, a Hausman test is needed to find out. The Hausman test can be defined as a statistical test to determine if the Fixed Effect or Random Effect model is best used. The Hausman Test is based on the following hypothesis:

$\mathrm{H} 0=$ Random Effect Model

H1 = Fixed Effect Model

This Hausman test statistic follows the distribution of Chi Square statistic with degree of freedom of $\mathrm{k}$, where $\mathrm{k}$ is the number of independent variables. If the Hausman statistic value is greater than the critical value then $\mathrm{H} 0$ is rejected and the exact model is the Fixed Effect model whereas on the other hand if the Hausman statistic is smaller than the critical value then the exact model is Random Effect or if the p-value of the Hausman test is significant (more less than 5\%) then $\mathrm{H} 0$ is rejected, meaning it is better to use FEM method. In table 8 . the results of the Hausman test are performed using Eviews 10.

Table 8. Hausman Test Results

\begin{tabular}{|c|c|c|c|}
\hline Test Summary & $\begin{array}{l}\text { Chi-Sq. } \\
\text { Statistic }\end{array}$ & Chi-Sq. d.f. & Prob. \\
\hline Cross-section random & 5.681066 & 1 & 0.0171 \\
\hline
\end{tabular}

From the table 8, it is known that the p-value (prob) is 0.0171 (smaller than 0.05), then $\mathrm{H} 0$ is rejected and $\mathrm{H} 1$ is accepted so that the Random Effect model is better.

Hypothesis Testing

A hypothesis is a conclusions or conclusions that can be formulated without certainty. So to know whether or not the hypothesis is large. Then the test should be done first. Test the partial regression coefficients or $t$ tests to see if the independent variables individually affect the dependent variables.

The value of bad credit regression coefficient is -0.689467 and significant value $0.0001<0.05$ can be concluded that the bad credit (NPL) variable has a significant negative impact on profitability. Thus the hypothesis that bad credit (NPL) significantly affects profitability (ROA) is proven and accepted.

\section{Discussion}

Based on the test results that have been described statistically by using the Eviews 10 program, it shows that nonperforming loans has a significant negative effect on profitability. This is proven by showing a negative influence where the value of $\mathrm{t}=-4.466879$ and significant because $\mathrm{p}=0.0001(\mathrm{p}<0.05)$. This value is below the significance level of 0.05 or $5 \%$, it can be concluded that H0 is rejected and H1 is accepted so that bad credit significantly 
influences profitability. The non-performing loan regression coefficient of -689467 which has a negative value indicates a negative relationship with profitability. Bad credit affect profitability because all loans have a high risk, because if the debtor fails or experiences problems in fulfilling the obligations that have been determined can cause harm to the bank.

This is due to high bad credit that results in profitability. NPL has a negative and significant impact on ROA. This means that in the event of an increase in NPL the ROA will decrease as well. This result is in line with the study of Sari (2009) which studies indicate that NPLs have a negative and significant impact on ROA acceptable. The increase in NPLs will affect the ROA (Profitability) of the bank, as the higher the NPLs the worse the credit quality of the bank will be, resulting in a higher credit score, and therefore the bank will have to suffer losses in the bank's operations and thus affect the ROA acquired by the bank. Low NPLs indicate that the bank's financial performance is improving. This is contrary to the current theory that the size of the credit line will determine the bank's profitability. If the bank is unable to provide the credit it will cause the bank to lose (Kasmir, 2014). This result is also not in line with research that found that the amount of credit given has a significant positive impact on the profitability of the banking company (Saputra dan Nasution, 2009).

Basically there is a major function of banks lending credit which is profitability. Profitability is the goal of earning a credit result in the interest of interest payable by the customer which will increase profitability, so credit is the dominant asset (Rivai, et al. 2007). However, credit cannot always determine the rise or fall of a company's profitability, since the components that make up profitability are not just credit-generated interest rates but other components.

Based on the Random Effect model it shows that the Bank's BRI Lending Rate (NPL) is positively related to its profitability of 0.285995 . At Bank BNI is -0.036145 , Bank Mandiri is -0.114314 , BTN Bank is -0.135537 , from the above results indicate that NPL level negatively affects Bank BRI, Bank BNI, Bank Mandiri and BTN Bank.

The rising NPL level is at BTN Bank of -0.135537 which means that the bank's health level is not good for investors who want to invest in BTN Bank. The NPL level $2 \%$ increase in the case of BTN Bank. The lowest level of NPLs in BNI Bank is 0.59\%.

The level of Profitability experienced by the BRI Bank is the highest. BRI bank health is good for investors who want to invest their shares in the banking company as the Profitability Levels fell below 2\% from 2010 to 2017. While the decline in profitability each year shows the Bank's poor health level, it is on Bank Mandiri as profitability dropped to below $1 \%$ by $0.38 \%$.

\section{Conclusion}

Bad credit measured by NPL affects the level of profitability of state-owned banks listed on the Indonesia Stock Exchange as measured by ROA.

The higher the bad credit, the worse the bank's credit quality is, and the higher the bad credit score.

Bad Credit has a negative and significant impact on Profitability as the increased bad credit can result in the bank's reduced ability to earn a profit.

This research can be continued using additional variables such as capital adequacy ratio and loan to deposit ratio.

\section{References}

Budisantoso, Totok dan Sigit Triandaru. (2006). "Bank dan Lembaga Keuangan Lainnya”, Edisi 2. Jakarta: Salemba Empat

Kasmir. (2014). "Bank dan Lembaga Keuangan Lainnya”. Edisi Revisi 2014. Raja Grafindo Persada. Jakarta.

Kuncoro, M. dan Suhardjono. (2002). "Manajemen Perbankan: Teori dan Aplikasi”. Edisi Pertama. Yogyakarta: Salemba Empat.

Rivai, Veithzal, dkk, (2007). "Bank And Financial Institution Management Conventional \& Sharia System”. Raja Grafindo Persada.

Saputra, Hendra dan Fahmi Natigor Nasution. (2009). "Pengaruh Jumlah Kredit yang Diberikan dan Tingkat Likuiditas Terhadap Profitabilitas Perusahaan Perbankan". Jurnal Akuntansi Indonesia.

Siamat, Dahlan. (2001). "Manajemen Lembaga Keuangan”, Edisi 2, Cetakan ke-2. Jakarta: Fakultas Ekonomi Universitas Indonesia.

Suharno. (2003). "Analisa Kredit". Djambatan, Jakarta.

Tumiwa, Ramon Arthur Ferry., Made Sudarma, Ubud Salim and Djumahir. (2013). Banking Regulation, Risk Management and Capital Structure Decisions: A Study on Rural Banks in Indonesia. Research Journal of Finance and Accounting. Vol.4, No.15. P. 27-35. 